\title{
Effects of Organic and Inorganic Fertilizers on the Growth and Yield of Physic Nut (Jatropha Curcas)
}

\author{
Oliver Echezona Ngwu
}

\begin{abstract}
The research was conducted in 2011 cropping season at the Teaching and Research farm of the Faculty of Agriculture and Natural Resources Management, Enugu State University of Science and Technology, Enugu, Nigeria to study the effect of organic and inorganic fertilizers on the growth and yield of physic Nut (Jatropha curcas). There were five treatments namely, control, (no application of treatment), NPK 20:10:10, NPK 15:15;15, poultry droppings and goat dung. The treatments were laid out in a Randomized complete Block Design (RCBD) with five replications. The total land area used was $228 \mathrm{~m}^{2}(19 \times 12 \mathrm{~m})$ while the plot size was $3 \mathrm{mx} 2\left(6 \mathrm{~m}^{2}\right)$. The growth parameters measured were plant height, number of leaves, and leaf area, index (LAI).

The results obtained showed that there were significant differences at $\mathrm{P}=0.05$ among the different treatments in 30 , to and 90 DAP.

Based on the results T4 (poultry droppings) had higher effect at $\mathrm{P}=0.05$ at $30,60,90 \mathrm{DAP}$ than the other treatments when compared and is hereby recommended as the best type of fertilizer for the optimum growth and production of physic Nut (Jatropha Curcas) in South Eastern Nigeria.
\end{abstract}

Keywords - organic, Inorganic fertilizers, growth, yield, Jatropha curcas.

\section{INTRODUCTION}

Physic nut (Jatropha Curcas) is a bio-diesel crop belonging to the family of Euphorbiaceace which comes from the genus Jatropha. It is a large shrub native of Central America and Mexico co-traditionally grown as a hedge in countries of SubSaharan Africa, tropical and other sub tropical regions of the world. The name (Jatropha curcas) is derived from the Greek words (iatros) meaning "physician" and (trophe) meaning "nutrition" hence the common name physic Nut. It is also referred to as "Lapalapa" by the Yorubas, "Chinidazugu" by the Hausas, Okwueme" by the Igbos and it is also called "Boboochi" by the natives of Agbani and Obe village in Nkanu Local Government Area in Enugu State, Nigeria.

Physic Nut is a drought resistant perennial that can grow in wastelands even on gravelly, sandy and saline soils, flowering usually once a year but under certain conditions can flower almost throughout the year like in permanently humid regions or under irrigation and fertilization. The ideal climate

Department of Agronomy \& Ecological Management, Enugu State University of Science and technology, Enugu State, Nigeria

Author's Phone: +2348036764402. E-mail:ngwuoe@yahoo.com for Jatropha can be summarized as an annual rainfall not exceeding $600 \mathrm{~mm}$ in moderate climate conditions, $1200 \mathrm{~mm}$ in hot climatic zones and soil $\mathrm{pH}$ less than 9 [4]. The atmospheric temperature is $20^{\circ} \mathrm{c}$ as the plants are sensitive to ground frost that may occur in winter. Jatropha grows in soils that are quite infertile, usually found at lower elevations sometimes below 500mm [7] and it can also be grown in deserts due to its resistance to high degree of aridity.

Physic nut leaves are smooth, large and green to pale green in color measuring 4-6lobes and $10-15 \mathrm{~cm}$ in length and width. It I a monoecious plant and the terminal inflorescence contains unisexual flowers which flowers normally once a year during rainy season [8]. Flowers are formed terminally and individually with female flower usually slightly larger, this occurs in the hot seasons, in conditions where continuous growth occurs, and imbalance of pistillate or staminate flower production results in a higher number of female flowering. After pollination, the inflorescence form a bunch of green ellipsoidal fruits, the blackish seeds contains toxins such as trypsin, inhibitors, lectins and phytates to such levels that the seed oil and seed cake are not edible without detoxification [2]. The seeds possess toxicity which it develops after 5-6 months. Therefore it is vulnerable to animal attack until that moment. When planting, the normal planting distance is $2 \mathrm{~m}$ $\mathrm{x} 2 \mathrm{~m}, 2.5 \mathrm{~m}$ and $3 \mathrm{mx} 3 \mathrm{~m}$.

There are four important species of Jatropha which are Jatropha curcas, gossitifolia, Jatropha podarica and Jatropha multifida [6] but in the recent past, jatropha curcase have been chosen and considered the most potential species for varying situations not only to the growers but also to the processers and end user as well. Products of the tree crop are now gaining ground all over the world especially in making Bio-diesel to power engines as well as various household medicinal uses. Being an energy plant, Jatropha curcas may utilize large quantities of nutrients from the soil and will definitely deplete soil fertility if not properly fertilized. It is also very important to improve on the production of such valuable plant through fertilizer application because of the major essential renewable source of energy derived from it. Furthermore, its cultivation can create regular employment opportunities to the rural societies as it provides a never ending marketing potential. However, the effect of fertilizer application during germination is negative on the plant growth but favourable if applied after germination is achieved. N.P.K fertilizer helps to promote 
plant growth, while poultry manure also increases plant growth and crop yield making the leaves greenish and fresh thereby causing the soil to release some of its store of plant food in a form that it can be absorbed by plants easily [3].

\section{A. Objective of the study}

The objective of this study is to determine the effect of organic and inorganic fertilizers on the growth and yield of Physic Nut.

\section{MethodOLOGY AND METHODS}

\section{A. Experimental site}

The research experiment was carried out during 2011 cropping season at the Research and Teaching Farm of the Faculty of Agriculture and Natural Resources Management, Enugu State University of Science and Technology, Enugu. The area is characterized by an annual rainfall between $1700 \mathrm{~mm}$ to $1800 \mathrm{~mm}$ and a humid tropical climate with wet season between (April-October) and dry season between (November - March).

\section{B. Soil Laboratory Analysis}

Soil sampling and analysis were carried out before and after planting. Soil samples were collected with soil auger from different parts of the experimental site and were bulked later to produce a composite sample. The soil analysis was done to determine the soil nutrient level and other soil properties like soil $\mathrm{pH}$, cation exchange capacity.

\section{Soil pH}

Was determined using both distilled water and $0.1 \mathrm{kCl}$ solution [9].

\section{Particle Size}

This was determined using Bouyoucous hydrometer method [10].

\section{E. Organic Carbon}

Was determined using Walkley - Black method [11].

\section{F. Cation Exchange Capacity}

The cation exchange capacity of the soil was determined using Ammonium acetate method [12].

\section{G. Exchangeable Base}

This was determined using complexiometric titration method described by [13].

\section{H. Available Phosphorus $(P)$}

This was determined by using Bray II solution [14].

\section{Total Nitrogen} [15].

This was obtained using Micro Kjedahl distillation method

\section{J. Sources of Material}

The Jatropha seeds used for this experiment were obtained from Federal Ministry of Agriculture and Rural Development farm, Abuja while the NPK fertilizers and inorganic manure were purchased from ENADEP.

\section{K. Field Preparation}

The experimental site was cleared, ploughed and ridged manually and marked. The marking was done using a measuring tape, pegs and ropes to map out a total land area of $(19 \mathrm{~m} \times 12 \mathrm{~m})$ which was used for the experiment. The field was divided into five blocks and five experimental units making a total of 25 plots. The spacing between the blocks is $1 \mathrm{~m}$ while the distance between the treatments is $0.5 \mathrm{~m}$ each. The planting depth was $2 \mathrm{~cm}$. Three seeds were planted in a hole and thereafter thinned to one seed per hole. The planting distance was $2 \mathrm{~m} \times 2 \mathrm{~m}$. The treatments were replicated five times in a Randomized Complete Block Design (RCBD).

\section{Experimental Design and Treatments}

The experimental design used was Randomized Complete Block Design (RCBD) with 5 replication and 5 treatments.

\section{The Treatments Used Were}

\section{$\mathrm{T} 1=$ Control}

T2=NPK 20:10:10 at $100 \mathrm{~kg} / \mathrm{ha}$

T3=NPK 15:15:15 at 5rons/ha

T4=Poultry Droppings at 5tons/ha

$\mathrm{T} 5=$ Goat dung at 5tons/ha

Owing to the report by forest science and technology volume 7 issue 22010 on the effect of NKP fertilizers (NPK 20:10:10 and NPK 15:15:15) on the growth and yield of Jatropha curcas which was said to have a positive response to NKP 20:10:10 than NPK 15:15:15 because of the high $\mathrm{N}$ levels supply which supplies enough nutrients for high productivity. According to the trial experiment conducted on this, it showed that the highest positively induced growth of $80 \%$ was recorded at the dosage of $100 \mathrm{~kg} / \mathrm{ha}$ of NPK 20:10:10 and NPK 15:15:15 at the same dosage gave $75 \%$.

\section{Field Layout}

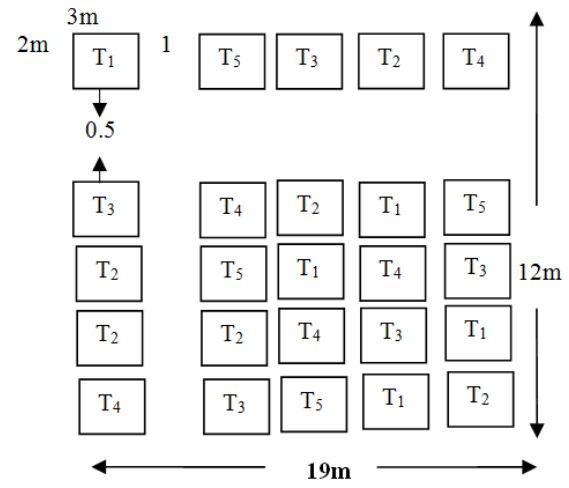

Fig. 1: Field layout of various treatments and replications in Randomized Complete Block Design (RCBD).

\section{N. Cultural Practices}

Adequate field maintenance was carried out to ensure that the crop performs well. Weeding was done manually at two weeks interval. Fertilizer application was carried out two weeks. 


\section{O. Data Collection}

The following agronomic data were collected.

\section{P. Plant Height (cm)}

This was measured as the length from the base of the plant to the tip of the shoot. The height of three plants selected randomly were measured and their mean taken. This was done with the aid of a meter rule.

\section{Q. Number of Leaves}

This was determined by counting the total number of leaves per plant. This was counted in three plants per plot selected randomly and their mean was taken.

\section{R. Leaf Area Index}

This was determined by measuring the length and width of a leaf with meter rule. These were measured on leaves, one for each plant per plot. The result was calculated using the formula below

\section{$\mathrm{LAI}=\underline{\mathrm{L}} \times \mathrm{W}$. of leaves $\mathrm{x} \mathrm{N}$ of leaves on the plant Area covered}

Where; $\mathrm{L}=$ Length, $\mathrm{W}=$ Width of leaves, $\mathrm{N}=$ Number of leaves

\section{S. Statistical Analysis}

The analysis of variance (ANOVA) was carried out according to the procedure, outlined by [17]. Randomized Complete Block Design (RCBD) and detection of differences between treatment means was done as outlined by [16] and the separation of treatment means for significant effects was done using the Fishers significant difference (FLSD) techniques.

TABLE I

FORM OF ANALYSIS OF VARIANCE (ANOVA) USED FOR THE STUDY

\begin{tabular}{ccc}
\hline Source of Variation & $\begin{array}{c}\text { Degree of Freedom } \\
\text { (General) }\end{array}$ & $\begin{array}{c}\text { Degree of Freedom } \\
\text { (Specific) }\end{array}$ \\
\hline Block & $(\mathrm{r}-1)$ & 4 \\
Treatment & $(\mathrm{t}-1)$ & 4 \\
Error & $(\mathrm{r}-1)(\mathrm{t}-1)$ & 16 \\
Total & $(\mathrm{rt}-1)$ & 24
\end{tabular}

\section{RESULTS AND DISCUSSION}

The results of the soil physical and chemical properties and crops parameters are represented in this section

Table II and III show the particles size distribution as well as the chemical properties of the soil before and after the experiment.

\section{A. Effect of Soil Physical and Chemical Properties on the} Growth and Yield of Physic Nut

The soil test values result showed that the soil textural class before planting was Sandy Loam. In the pre-planting analysis, the percentage of Sand was $70-40 \%$, Silt $17.40 \%$, clay $12.20 \%$, bulk density $1.28 \mathrm{mgm}^{-}{ }^{3}, \%$ Porosity 5.69 . At 90 days after application of organic and inorganic fertilizers, the soil textural class was sandy loam with Sand $56.40 \%$, Silt
$24.40 \%$, Clay, $19.20 \%$ bulk density $1.38 \mathrm{mgm}^{-3}, \%$ porosity 48.30.

The $\mathrm{P}^{\mathrm{H}}$ before application of organic manure and inorganic fertilizers was 5.28 and later increased to 5.90 after application, this may be due to the fertilizers applied to the soil.

The result of the experiment also showed that before the soil was treated with organic and inorganic fertilizer, the total nitrogen was $0.049 \%$ and after application, it increased to $0.184 \%$. phosphorus $(\mathrm{P})$ before application was $7.00 \%$ and after application it increased to 10.80 and total $\mathrm{K}$ before application was $0.173\left(\mathrm{Cmol}^{+\mathrm{kg}-1}\right)$ and after application $\mathrm{k}$ increased to $0.2850\left(\mathrm{Cmol}^{+\mathrm{kg}-1}\right)$.

TABLE II

PHYSICAL PROPERTIES OF THE SOIL BEFORE AND AFTER THE EXPERIMENT

\begin{tabular}{lll}
\hline Parameters & Before & After \\
\hline \% Sand & 7.40 & 56.40 \\
$\%$ Silt & 17.40 & 24.40 \\
\% Clay & 12.20 & 19.20 \\
Texture & SL & SL \\
B/density mgm ${ }^{3}$ & 1.28 & 1.38 \\
\% Porosity & 51.69 & 48.30 \\
\hline
\end{tabular}

TABLE III

CHEMICAL PROPERTIES OF THE SOIL BEFORE AND AFTER THE EXPERIMENT

\begin{tabular}{lll}
\hline Parameters & Before & After \\
\hline $\mathrm{pH} \mathrm{H} \mathrm{O}_{2} \mathrm{O}$ & 5.28 & 5.90 \\
$\mathrm{pH} \mathrm{KcL}$ & 4.80 & 5.70 \\
$\% \mathrm{Oc}$ & 0.57 & 0.74 \\
$\% \mathrm{Om}$ & 0.98 & 1.27 \\
$\% \mathrm{~N}$ & 0.049 & 0.184 \\
$\mathrm{P}\left(\mathrm{mg} / \mathrm{Kg}^{-}\right)$ & 7.00 & 10.80 \\
$\mathrm{Ca}\left(\mathrm{Cmol}^{+} \mathrm{kg}^{-1} 1\right)$ & 4.20 & 8.40 \\
$\mathrm{Mg}\left(\mathrm{Cmol}^{+} \mathrm{kg}^{-1}\right)$ & 2.40 & 5.30 \\
$\mathrm{~K}\left(\mathrm{Cmol}^{+} \mathrm{kg}^{-1}\right)$ & 0.173 & 0.285 \\
$\mathrm{Na}\left(\mathrm{Cmol}^{+} \mathrm{kg}^{-1}\right)$ & 0.087 & 0.128 \\
$\mathrm{EA}\left(\mathrm{Cmol}^{+} \mathrm{kg}^{-1}\right)$ & 1.04 & 1.28 \\
$\mathrm{ECEC}$ & 7.90 & 15.393 \\
& & \\
$\% \mathrm{BS}$ & 86.83 & 91.68 \\
\hline
\end{tabular}

\section{B. Effect of Organic and Inorganic Fertilizers on the Mean} Plant Height (cm) Physic Nut (Jatropha curcas)

The results presented in table Iv shows a significant difference between (0.05) among some of the treatment in terms of mean plant height.

At 30DAP there were significant difference between plots of T1 (control) 12.588 and T4 (poulty droppings) 17.958, T1 and T5 (goat dung) 17.288. T1, T2 (NPK 20:10:10) and T3 (NPK 15:15:15) had no significant difference between (0.05). In other words they are statistically the same. This was also the same for 60 and 90DAP.

Therefore Treatment 4 (poultry droppings) and Treatment 5 (goat dung) of $47.88 \mathrm{~cm}$ and $45.88 \mathrm{~cm}$ respectively gave the higher plant height when compared with the other treatments. This increase is as a result of the organic fertilizer applied. This is in line with [10] who reported that organic fertilizer improves the health and productivity of the soil and plant as they provide different essential nutrients encouraging plant 
growth and increasing the abundance of soil organisms such as fungal mycorrhiza which aids plants in absorbing nutrients.

TABLE IV

EFFECT OF TREATMENTS ON THE MEAN PLANT HEIGHT (CM) OF PHYSiC NUT

\begin{tabular}{llll}
\hline \multicolumn{4}{c}{ DAYS AFTER PLANTING (DAP) } \\
\hline TREATMENTS & 30 & 60 & 90 \\
\hline Control & 12.588 & 23.89 & 31.78 \\
NPK20:10:10 & 16.578 & 29.87 & 43.74 \\
NPK15:15:15 & 14.436 & 27.26 & 38.52 \\
Poultry droppings & 17.958 & 31.94 & 47.88 \\
Goat dung & 17.288 & 30.94 & 45.88 \\
F.LSD(p=0.05) & 5.21 & 8.15 & 16.31 \\
\hline
\end{tabular}

\section{Effect of Organic and Inorganic Fertilizers on the Mean}

Number of Leaves of Physic Nut (Jatropha curcas)

The results presented in Table $\mathrm{V}$ showed that there are some significant differences at (0.05) among the treatments in terms of mean number of leaves. The result also show that Treatment 4 (poultry droppings) had the highest mean number of leaves of 15.856 while Treatment 1 (control) had the least number of leaves of 10.23 at 30 DAP

At 60 DAP the result shows that there is a significant difference at (0.05) among the treatments. Treatment 4 had the highest number of leaves of 28.79 while treatment I had the least number of leaves of 20.38. There is a significant difference.

The result also shows that there is a significant different at (0.050) among the treatments at 90 DAP. Treatment 4 had the highest number of leaves of 41.58 while treatment I had the least number of leaves of 24.70 there were significant different Treatment 1 and Treatment 4.

Therefore Treatment 4 (poultry droppings) had the highest numbers of leavers. This agrees with [1] that poultry droppings contain more plant nutrients than all other fertilizers (organic/inorganic) and [3] that poultry manure increase the chlorophyll content of the leaves causing the soil to release some of its store plant nutrients in a form that it can be easily absorbed by plants.

TABLE V EFFECT OF TREATMENTS ON THE MEAN NUMBER OF LEAVES OF PHYSIC NUT

\begin{tabular}{|c|c|c|c|}
\hline \multicolumn{4}{|c|}{ DAYS AFTER PLANTING (DAP) } \\
\hline TREATMENTS & 30 & 60 & 90 \\
\hline Control & 7.024 & 20.35 & 24.70 \\
\hline NPK20:10:10 & 12.789 & 23.56 & 31.12 \\
\hline NPK15:15:15 & 12.692 & 23.01 & 30.02 \\
\hline Poultry droppings & 17.024 & 28.79 & 41.58 \\
\hline Goat dung & 12.88 & 24.01 & 32.02 \\
\hline F.LSD $(p=0.05)$ & 5.783 & 8.80 & 17.61 \\
\hline
\end{tabular}

D. Effect of Organic and Inorganic Fertilizers on the Mean Leaf Area Index of Physic Nut (Jatropha curcas)

The results presented in table VI shows that there were significant differences at (0.05) among treatments in terms of mean leaf area index of 17.04 while Treatment (1) had the least of area index of 7.024 at 30 DAP. There were some significant differences between Treatments I and 2, 3, 4, 5. In order words treatment 2, 3, 4, and 5 are significantly the same. At 60 DAP, the result shows that Treatment 94) had the highest leaf area index of 26.54 while Treatment (1) had the least leaf area index of 11.642. There were significant difference at (0.05) between Treatment (1) and the other treatments when compared. At 90 DAP, the results showed that Treatment 4 (Poultry dropping) had the highest leaf area index of 45.0894 while Treatment (1) had the least leaf area index of 15.0912. There were significant difference at (0.05) among Treatment 41 while the rest of the treatments were significantly the same.

TABLE VI

EFFECT OF TREATMENTS ON THE MEAN LEAF AREA INDEX OF PHYSIC NUT

\begin{tabular}{llll}
\multicolumn{4}{c}{ DAYS AFTER PLANTING } \\
\hline TREATMENTS & 30 & 60 & 90 \\
\hline Control & 7.024 & 11.542 & 15.0912 \\
NPK20:10:10 & 12.798 & 20.20 & 32.4088 \\
NPK15:15:15 & 12.692 & 19.535 & 32.0856 \\
Poultry droppings & 17.024 & 26.54 & 45.0894 \\
Goat dung & 12.88 & 20.324 & 32.6558 \\
\hline F.LSD $(\mathrm{p}=0.05)$ & 5.73 & 8.92 & 33.1524 \\
\hline
\end{tabular}

\section{CONCLUSION AND RECOMMENDATION}

Jatropha curcas growth as demonstrated by plant height $(\mathrm{cm})$, number of leaves and leaf area index were significantly influenced by the application or organic and inorganic fertilizer. But organic manure especially poultry droppings has been observed to significantly increase Jatropha curcas growth when compared to the others. Treatment4 (poultry droppings) also proved to have a significant promotive effect $(\mathrm{p}=0.05)$ on Jatropha curcas seedling growth. This is in line with [1] report that poultry droppings contain more plant nutrients than all other fertilizers (organic/inorganic).

Although Jatropha curcas has the ability to flourish under any condition even without fertilizer application but greater yield is obtained when fertilizer is applied as observed from the research work.

From the result obtained in this study it shows that organic fertilizers (poultry droppings) are essential for the seedling growth of Jatropha curcas but response depends largely on time of application. Application time is preferably 2 weeks after germination but not during germination as it does not favour Jatropha growth. Therefore if Jatropha growers are informed about the importance of fertilizer application on Jatropha, benefits derived from this plant will be maximized.

This study has shown that Treatment 4 (poultry droppings) were most effective in maintaining Jatropha curcas seedling growth.

\section{RECOMMENDATION}

The observations and findings obtained from the experiment on the effect of organic and inorganic fertilizer on the growth and yield of physic nut (Jatropha curcas) shows that maximum production of physic nut can be achieved from treatment 4(poultry droppings) if properly managed in South Eastern part of Nigeria.

\section{REFERENCES}

[1] Ali G, (2005) Uses of manure and fertilizer as soil management technique for sustainable crop production, paper presented at a workshop organized 
by Taraba State Local Government Service Commission 9th December, 2005. P. 5.

[2] Aregheore E, Becker K and Makkar, (2003) Detoxification of toxic variety of Jatropha using leaf and chemical treatment and preliminary evaluation with rats. South Pacific Journal of Natural Science, 21:50-56.

[3] Burkitt, (2007) Comparing irrigated biodynamic of soil and pasture properties. Journal of Experimental Agriculture, 47:248-253.

[4] Foldi N, M. Sanchez, Mittleback M and Hackle S, (1996) Jatropha curcas Linnaeus as a source for the production of biofuel in Nicaragua, Biological resources Technology, 58:77-82.

[5] Jahn G (2004) effect of soil nutrients on the growth, survival and fecundity of insect pest of rice: an overview and theory of pest outbreaks with consideration of research approaches. Multi tropic interaction is soil and integrated control. WPRS Bulletin, 27(1): 115-122.

[6] Openshaw, (2008) A view of Jatropha curcas, an oil plant of unfulfilled promise. Biomass and Biological Energy, 19:1-5. http://dx.doi.org/10.1016/S0961-9534(00)00019-2

[7] World Bank, (2002). World Bank in Jatropha concept.

[8] Raju, A.B. and Ezradanam, L. (2002). Physiological characteristics of Jatropha Vol. 20, pp. 30-31.

[9] Mclean, E.O. (1982). Soil $\mathrm{pH}$ and lime requirement in soil analysis chemical and microbial properties (2nd edition). Agronomy series No. 9 ASA, SSSA, Madison USA, pp. 50-55.

[10] Bouyoucous, C.J. (1981). Hydrometer method improved for making particle size analysis of soil. Soil Science Society of America Proceedings, 26: 446-465.

[11] Walkley, A. and Black, C.A. (1934). Determination of organic carbon in soil science, 37: 29-38.

[12] Dewis, J. and Freitas, F. (1970). Physical and chemical method of soil and water analysis, Soil bulletin. 10. FAO, Rome.

[13] Chapman, H.D. (1982). Total exchangeable bases in black method of soil analysis part 2. ASA 9 Madison, pp 902-904.

[14] Bray, P.H. and Kurtz, L.T. (1945). Determination of total organic and available forms of phosphorus in soils. Soil science, 59: 39-45. http://dx.doi.org/10.1097/00010694-194501000-00006

[15] Bremner, J.M. and Mulvaney, C.S. (1982). Nitrogen total. In page, Methods of soil analysis part, Agronomy monograpgh, 9 (2nd edition) ASA and SSSA. Madison, WSC. pp. 403-430.

[16] Obi, I.U. (2002). Statistical methods of detecting differences between treatment means and research methodology issues in laboratory and field experiments. SNAAP Press Nigeria Limited Enugu. pp. 9-46.

[17] Steel, G. and Torrie, J.H. (980). Procedure of statistics. A biometrical approach (2nd edition) New York. Megrow Hill Box colpeny Inc. p. 633. 